\title{
Three formae speciales of Puccinia striiformis were identified as heteroecious rusts based on completion of sexual cycle on Berberis spp. under artificial inoculation
}

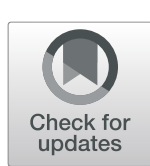

Shujie Huang ${ }^{\dagger}$, Shuxia Zuo ${ }^{\dagger}$, Dan Zheng, Yao Liu, Zhimin Du, Zhensheng Kang ${ }^{*}$ and Jie Zhao*

\begin{abstract}
Puccinia striiformis Westend. is an obligate biotrophic parasite that could infect wheat and grasses to cause stripe rusts. $P$. striiformis, a species of rust fungi, is divided into several formae speciales based on host specialization, including $P$. striiformis f. sp. tritici, P. striiformis f. sp. hordei, P. striiformis f. sp. elymi, P. striiformis f. sp. agropyri, and P. striiformis f. sp. secalis. Among the five forms of $P$. striiformis, sexual stage was confirmed only for the wheat form of the rust, $P$. striiformis f. sp. tritici, but not known for the rest four forms. In the present study, we investigated the host specialization of three forms of P. striiformis including P. striiformis f. sp. agropyri, P. striiformis f. sp. elymi, and P. striiformis f. sp. hordei, compared the morphology of their urediniospores and teliospores, and analyzed the molecular phylogenic tree of the three forms of $P$. striiformis and other related species in the genus Puccinia. Each of the three forms was able to infect barberry to complete pycnial and aecial stages under artificial inoculation. Further inoculations of grass, barley cv. Guoluo and wheat cv. Mingxian 169, highly susceptible to P. striiformis f. sp. tritici, using the resultant aeciospores showed that the aeciospores could successfully infect their respective hosts and produce uredinia with high infection types, with the exception on wheat cv. Mingxian 169 where only necrosis was observed. The results suggested that Berberis spp. were alternate hosts for the three formae speciales of $P$. striiformis, and confirmed that the three rusts were macrocyclic and heteroecious rust fungi completing the whole life cycle on primary hosts and alternate hosts. Our study provides a basis for studying pathogenic variation of the rust fungi through sexual hybridization between formae speciales of $P$. striiformis.
\end{abstract}

Keywords: Puccinia striiformis, Grass, Barley, Stripe rust, Alternate host, Sexual reproduction, Barberry

\section{Background}

Stripe (yellow) rust, caused by Puccinia striiformis Westend., is a common fungal disease damaging cereal crops and gramineous grasses (Liu and Hambleton 2010). The disease is spread by air-borne urediniospores for hundreds to thousands kilometers (Zadoks 1961; Brown and Hovmøller 2002; Hovmøller et al. 2002). Huge yield losses of crops resulted from epidemics of stripe rust often occurred in temperate areas where the summer is cool and the moisture is adequate for dew formation (Rapilly 1979;

\footnotetext{
* Correspondence: kangzs@nwafu.edu.cn; jiezhao@nwafu.edu.cn

tShujie Huang and Shuxia Zuo contributed equally to this work as co-first authors.

State Key Laboratory of Crop Stress Biology for Arid Areas, College of Plant Protection, Northwest A\&F University, Yangling 712100, Shaanxi, China
}

Li and Shang 1989; Zadoks and van den Bosch 1994). Wheat stripe rust is an important wheat disease in many countries, especially in China (Wan et al. 2007), the United States (Chen 2005), and some new stripe rust-invaded territories including Australia (Murray et al. 1994; Wellings 2007), New Zealand (Beresford 1982), and South Africa (Boshoff et al. 2002).

Stripe rust epidemics are often caused by new virulent races of $P$. striformis. In China, seven displacements of major wheat cultivars nationwide have happened since 1950 because of continuous emergence of new races (Wan et al. 2007). Recently, a few of new highly virulent races, V26 virulent to $Y r 24(=Y r 26+Y r C H 42)$ (Liu et al. 2010), G22-9 virulent to Guinong 22 (Yr10), Chuanmai 42 ( $\mathrm{rCH} 42$ ), 93R137 ( $Y r 26)$ and Moro (Yr10) (Jia et al.

(c) The Author(s). 2019 Open Access This article is distributed under the terms of the Creative Commons Attribution 4.0 International License (http://creativecommons.org/licenses/by/4.0/), which permits unrestricted use, distribution, and 
2012), and avrYr10/24/26/ch42 virulent to $\operatorname{Yr} 10, \mathrm{Yr} 24$, $\mathrm{Yr} 26$ and $\mathrm{YrCH} 42$ (Kuang et al. 2013), have been identified and found to evolve continuously to produce more new races. The new races caused 'break down' of the resistance of major wheat cultivars possessing the specific $Y r$ genes.

However, lack of sexual stage has made it difficult to study virulence variation of the rust fungi. Grasses and cereals harbor a massive of rust fungi, containing more than 380 species in genera of Puccinia and Uromyces, but only some of them are heteroecious (Cummins 1971). Most of the rust fungi do not have known alternate hosts for sexual reproduction. P. striiformis is a complex group of rust fungi and was first reported to have five formae speciales, namely $P$. striiformis f. sp. tritici (on wheat), P. striiformis f. sp. hordei (on barley), P. striiformis f. sp. agropyri (on Agropyron spp.), P. striiformis f. sp. elymi (on Elymus spp.) and $P$. striiformis $\mathrm{f}$. sp. secalis (on rye), based on host specialization by Eriksson and Henning (1894). Subsequently, other scientists reported four different formae speciales, including P. striiformis f. sp. dactylidis on orchard grass (Manners 1960; Tollenaa 1967), P. striiformis f. sp. poae on Kentucky bluegrass (Tollenaa 1967), $P$. striiformis $\mathrm{f}$. sp. leymi on Leymus secalinus (Niu et al. 1991), and P. striiformis f. sp. pseudo-hordei on wild barley grass (Hordeum spp.) (Wellings et al. 2000). In recent years, based on combined methods of spore morphology and sequences of internal transcribed spacer (ITS) and beta-tubulin DNA regions, the stripe rust fungi infecting bluegrass and orchard grass were renamed as $P$. pseudostriiformis M. Abbasi, Hedjaroude, and M. Scholle, and P. striiformoides M. Abbasi, Hedjaroude, and M. Scholle, respectively (Abbasi et al. 2004; Liu and Hambleton 2010). Liu and Hambleton (2010) suggested that the P. striiformis on grass species in genera of Aegilops, Elymus, Hordeum, and Triticum, should be recognized as P. striiformis sensu stricto. Until recently, alternate hosts for $P$. striiformis $\mathrm{f}$. sp. tritici causing wheat stripe rust and for $P$. pseudostriiformis (syn. $P$. striiformis f. sp. poae) on Poa pratensis has been reported (Jin et al. 2010), but the alternate hosts for other forms of $P$. striiformis have not been known. Therefore, the objective of the present study is to test whether barberry can serve as aecial hosts for the three forms of $P$. striiformis, $P$. striiformis $\mathrm{f}$. sp. agropyri (Psa), P. striiformis f. sp. elymi (Pse) and P. striiformis f. sp. hordei (Psh).

\section{Results}

\section{Host specialization of $P$. striiformis formae speciales}

Fifteen days post inoculation (dpi) of the single uredinium-derived isolates of the three $P$. striiformis formae speciales on their respective original hosts, heavy sporulation was observed on A. cristatum (Fig. 1a), E. cylindricus (Fig. 1b), and barley cv.
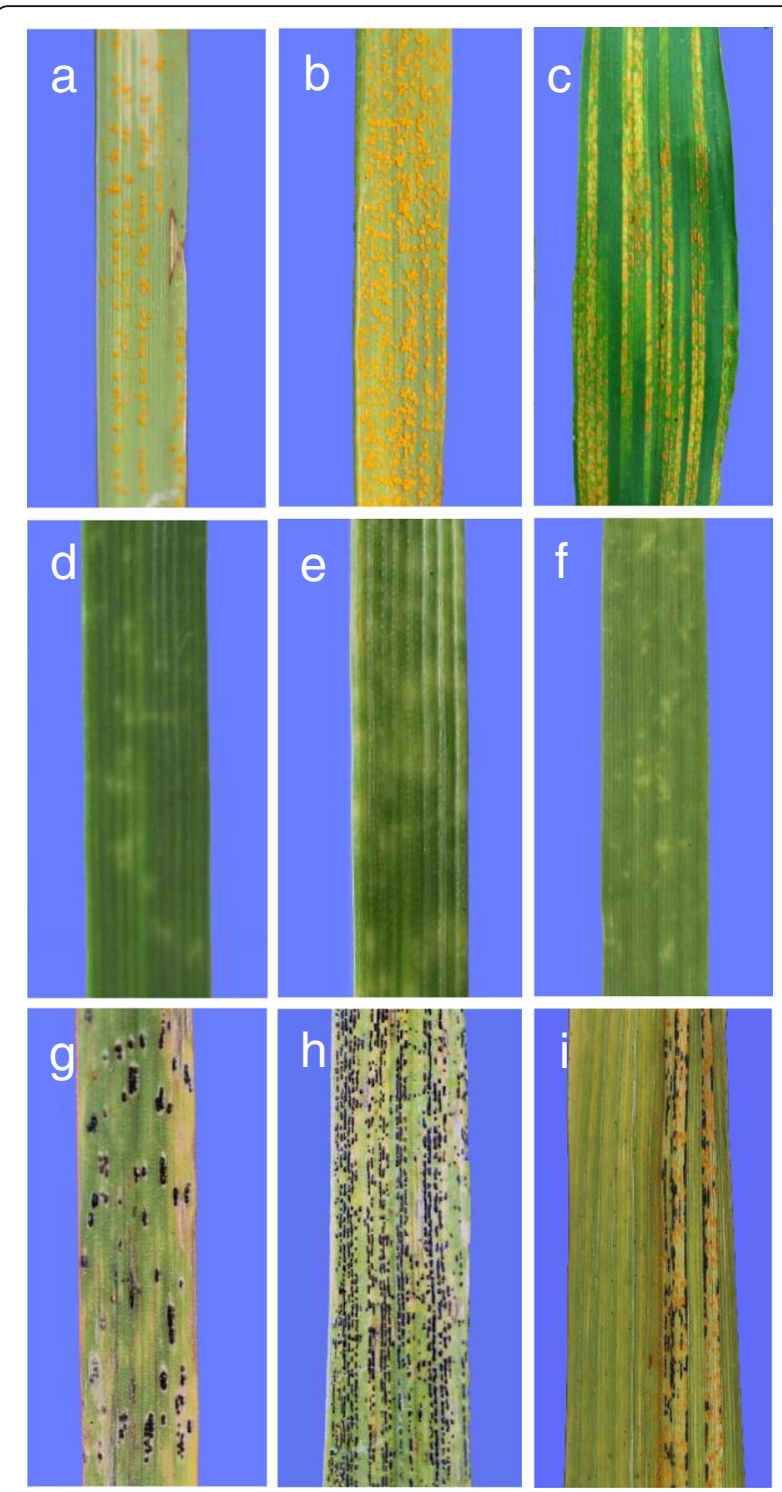

Fig. 1 Host specialization of formae speciales of Puccinia striiformis on their original hosts and wheat and the teliospore formation. $\mathbf{a}, \mathbf{b}$, c Uredinial stage of P. striiformis on Agropyron cristatum, Elymus cylindricus, and barley cv. Guoluo (Hordeum vulgare var. nudum). d, e, $\mathbf{f}$ Necrotic reaction of $P$. striiformis f. sp. agropyri, $P$. striiformis f. $s p$. elymi, and P. striiformis f. sp. hordei on wheat (cv. Mingxian 169). g, h, i Telial stage of stripe rust on A. cristatum, E. cylindricus, and barley cv. Guoluo. Bar = $50 \mu \mathrm{m}$

Guoluo (Fig. 1c), but not on wheat cv. Mingxian 169. Instead, necrosis lesions were produced on leaves of Mingxian 169 (Fig. 1d, e and f). Therefore, the three stripe rust pathogens infecting A. cristatum, E. cylindricus, and barley cv. Guoluo were determined to be P. striiformis f. sp. agropyri, P. striiformis f. sp. elymi, and $P$. striiformis f. sp. hordei, respectively. Subsequently, the three rust forms produced telia about 25 dpi (Fig. 1g, h and i). 
Morphology of three formae speciales of $P$. striiformis To further characterize the three forms of $P$. striiformis, morphology of their urediniospores and teliospores were assessed under a light microscope. Urediniospores of $P$. striiformis f. sp. agropyri on A. cristatum were near round in shape, single-celled, light orange in color, $23-34 \times 21-30 \mu \mathrm{m}$ (mean $28 \times 24 \mu \mathrm{m})$ in size (Fig. 2a). Teliospores were two-celled, single-celled occasionally, without or with a short stalk. The apical cell of teliospores was domed or inclined, $17-32 \times 15-28 \mu \mathrm{m}$ (mean $26 \times 21 \mu \mathrm{m}$ ). The lower cells of teliospores were $21-37 \times 12-21 \mu \mathrm{m}$ (mean $27 \times 16 \mu \mathrm{m})$. Teliospore stalks were $(0-)$ 1-6 $(-18) \mu \mathrm{m}$ (mean $4 \mu \mathrm{m}$ in length). The upper cells were brown, and darker than the lower cells (Fig. 2b).

Urediniospores of $P$. striiformis f. sp. elymi on $E$. cylindricus were fresh orange-colored, single-celled, near round or occasionally oblong in shape, 21-29x $19-26 \mu \mathrm{m}$ (mean $24 \times 22 \mu \mathrm{m}$ ) in size (Fig. 2c). The apical cells of teliospores were dark brown, flat or inclined, $19-32 \times 14-19 \mu \mathrm{m}$ (mean $23 \times 17 \mu \mathrm{m})$ in size. The lower cells of teliospores were $21-32 \times 9-16 \mu \mathrm{m}$ (mean $28 \times$ $11 \mu \mathrm{m})$. Teliospore stalks were (0-) 0.3-0.7 (1.3) $\mu \mathrm{m}$ long (Fig. 2d).

Urediniospores of $P$. striiformis $\mathrm{f}$. sp. hordei on barley cv. Guoluo were light orange, single-celled, near round in shape, and were averaged $26 \mu \mathrm{m}$ in diameter (Fig. 2e). Teliospores were light orange in color, two-celled, with a short stalk or without a stalk. The apical cells of teliospores were $27-30 \times 23-30 \mu \mathrm{m}$ (mean $29 \times 24 \mu \mathrm{m}$ ) in size. The lower cells of teliospores were $23-30 \times 21-25 \mu \mathrm{m}$ (mean $26 \times$ $23 \mu \mathrm{m})$. Teliospore stalks were (0-) 2.3-4.5 (7.3) $\mu \mathrm{m}$ long (Fig. 2f).

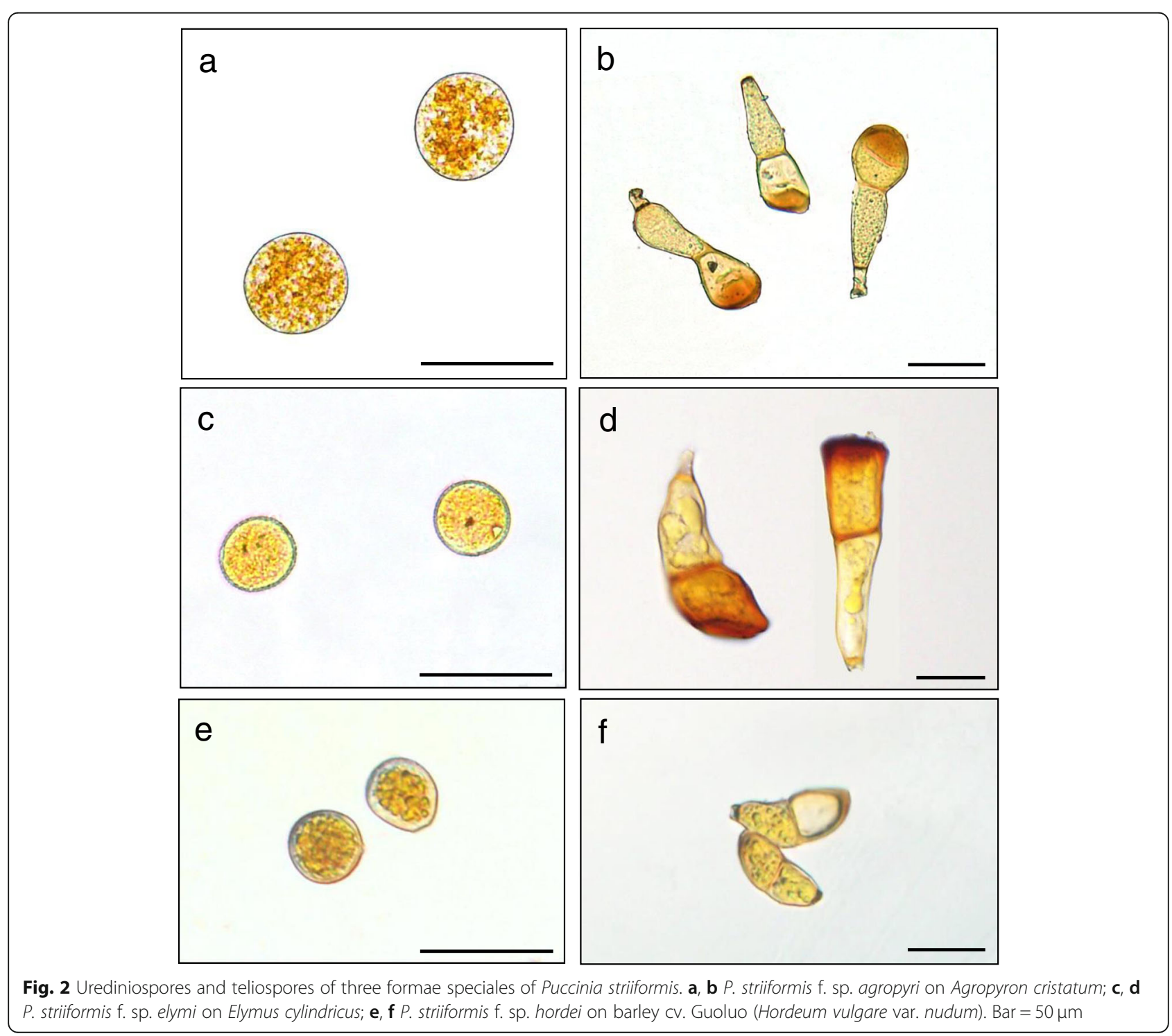




\section{Sequence analysis}

Alignment of ITS sequence of Agropyron form and Elymus form of $P$. striiformis as well as $P$. striiformis f. sp. tritici showed that they shared a high sequence similarity of $97.31 \%$ (Additional file 1: Figure S1), indicating that Agropyron form and Elymus form of rust fungi used in this study were P. striiformis. Agropyron form and Elymus form of P. striiformis presented a similarity of $95.05 \%$ and displayed obvious sequence difference in internal transcribed spacer region based on sequence alignment (Additional file 2: Figure S2). Phylogenic tree of the three forms of Puccinia striiformis used in this study, namely Psa (GenBank accession No.: MK418351), Pse (GenBank accession No.:MK418452), and Psh (GenBank accession No.:MK414678) and reference Puccinia species submitted in NCBI database (Table 1) indicated that Psh, Pse and Psa were grouped into one subclade with reference Puccinia striiformis formae speciales, including $P$. striiformis f. sp. hordei on Hordeum, P. striiformis f. sp. elymi on Elymus, P. striiformis f. sp. tritici on Triticum, and $P$. striiformis f. sp. agropyri on Aegilops, but distinguished from $P$. pseudostriiformis, $P$. striiformoides, $P$. coronata s. 1., and P. graminis (Fig. 3). The sequence analysis, together with host specialization, showed that the three forms of $P$. striiformis used in the present study were $P$. striiformis f. sp. hordei, P. striiformis f. sp. elymi, and $P$. striiformis $\mathrm{f}$. sp. agropyri, respectively.

Table 1 List of Puccinia species used in the phylogenetic analysis

\begin{tabular}{lll}
\hline Puccinia species & Host & GenBank accession No. \\
\hline P. pseudostriiformis & Poa pratensis & $\mathrm{HM} 057113^{\text {a }}$ \\
P. gansensis & Achnatherum inebrians & $\mathrm{HM} 057115$ \\
P. striiformis & Triticum aestivum & $\mathrm{HM} 057118$ \\
P. striiformis & Aegilops ligustica & $\mathrm{HM} 057127$ \\
P. striiformis & Hordeum sp. & $\mathrm{HM} 057128$ \\
P. striiformis & Elymus elymoides & $\mathrm{HM} 057130$ \\
P. striiformis & T. aestivum & $\mathrm{HM} 057135$ \\
P. striiformis & H. comosum & $\mathrm{HM} 057136$ \\
P. striiformoides & Dactylis glomerata & $\mathrm{HM} 057137$ \\
P. coronata s.l. & Avena sp. & $\mathrm{HM} 057140$ \\
P. graminis & T. aestivum & $\mathrm{HM} 057144$ \\
P. poae-nemoralis & Koeleria litvinowii & $\mathrm{HM} 057155$ \\
P. striiformis & Agropyron cristatum & $\mathrm{MK} 418351^{\mathrm{b}}$ \\
P. striiformis & E. cylindricus & MK418452 \\
P. striiformis & H. vulgare var. nudum & MK414678
\end{tabular}

${ }^{\mathrm{a}}$ Data of HM series of Puccinia species were originated from Liu and Hambleton (2010). bach of sequences of rust fungi used in this study was submitted to GenBank of NCBI Database (https://www.ncbi.nlm.nih.gov/) and was provided accession number, respectively
Pycnial and aecial production of the three formae speciales of $P$. striiformis on barberry

Seven to nine dpi, initial symptoms of tiny, light yellow lesions were visible at the early stage of the Pst infection on barberry leaves (B. shensiana). With the development of pycnia, lesions developed radially around the primary infection sites, showing dark yellow color in the centers of lesions (Fig. 4a, b and c). Simultaneously, massive pycniospores were produced inside a pycnium and moved upward to accumulate around the pycnial ostiole on the surface of barberry leaves, forming a transparent, oval drop of nectar. Nectars appeared yellow with a yellow background. After fertilization (spermatization), 13 to 16 dpi, orange, finger-shaped aecia emerged from the back side of a pycnial lesion (Fig. 4d, e and f), extending to several millimeters in length, generally 1 to $3 \mathrm{~mm}$. The number of aecial cups (aecia) differed from one lesion to another.

\section{Pathogenicity of aeciospores}

Aeciospores of three formae speciales of $P$. striiformis produced on barberry were used to inoculate their respective hosts, A. cristatum, E. cylindricus, barley cv. Guoluo, as well as wheat cv. Mingxian 169. Eighteen days after aeciospore inoculation, yellow uredinia were produced on leaves of $A$. cristatum, E. cylindricus, and barley cv. Guoluo (Fig. 4g, h and i), but not on leaves of wheat cv. Mingxian 169 on which only necroses were observed (Fig. $4 \mathrm{j}, \mathrm{k}$ and $\mathrm{l}$ ). Massive uredinia lined in arrays between leaf veins of the two grasses, A. cristatum and E. cylindricus, showing typical symptoms of stripe rust. The P. striiformis f. sp. hordei uredinia were scattered on leaves of barley cv. Guoluo seedlings probably due to the lack of vein tissues. Thus, these three forms were able to infect barberry and the resulted aeciospores could infect the grass hosts from which they were collected and produce uredinia but not on other plants tested.

\section{Discussion}

Puccinia striiformis frequently produces variants. Rust fungi from wild grasses could possibly harbor higher genetic variation than those from crops because of the selection on crop host. Cheng et al. (2016) reported that grasses harbor more diverse pathotypes of $P$. striiformis than cereals based on pathogenicity and DNA polymorphism of urediniospore isolates collected from wheat, barley, rye, grasses, and triticale in the United States. Our study of the alternate host for the three forms of $P$. striiformis has led us to hypothesize that sexual genetic recombination may contribute to diversity of this stripe rust pathogen. Up to now, only the tritici form of $P$. striiformis has been verified to produce new variants through sexual reproduction (Tian et al. 2016; 
0.05

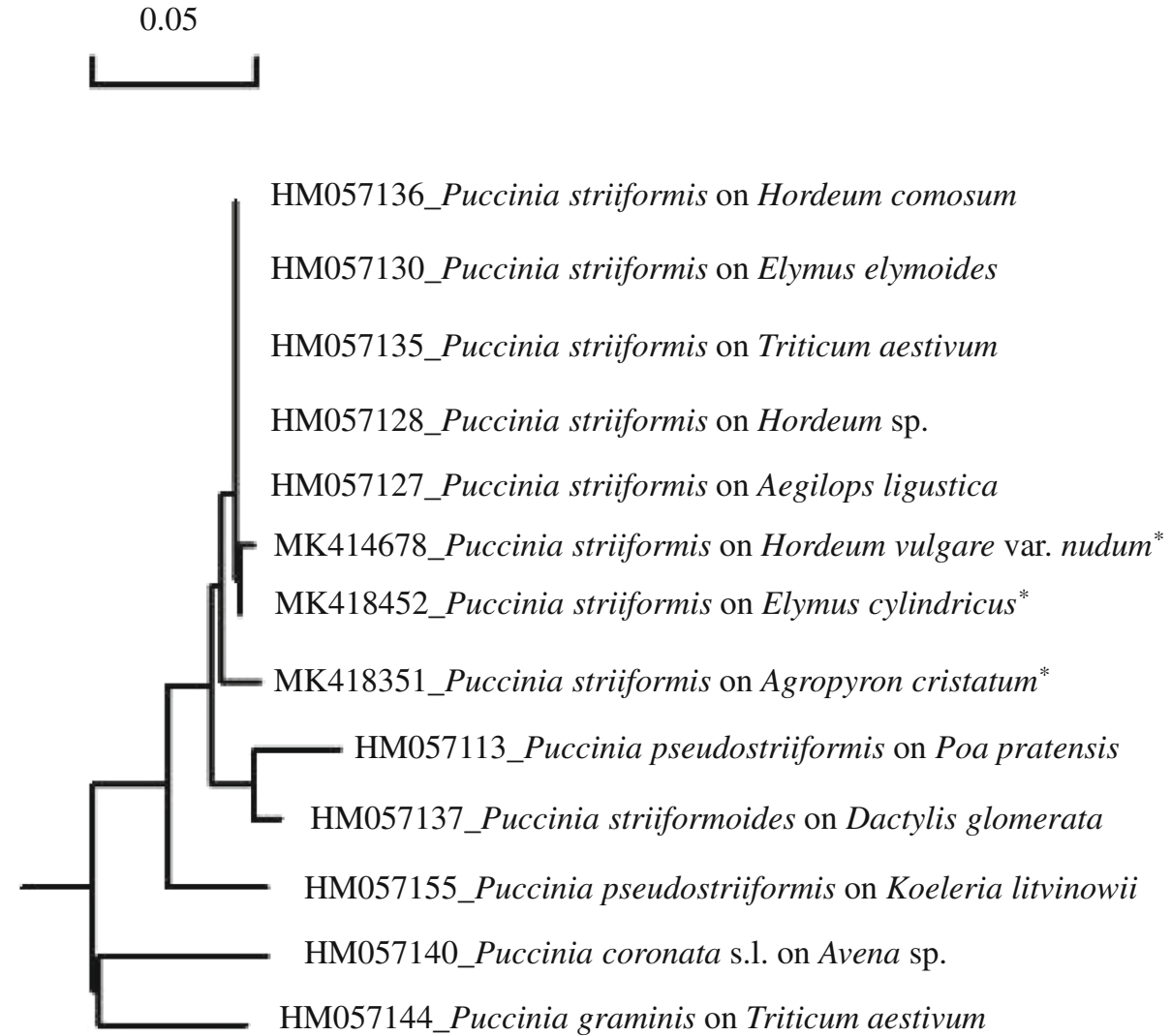

Fig. 3 Phylogenic tree based on ITS sequences of three formae speciales of Puccinia striiformis and the related species in Puccinia. ${ }^{*}$ P. striiformis $\mathrm{f}$. sp. hordei on Hordeum vulgare var. nudum (GenBank accession No.:MK414678), P. striiformis f. sp. elymi on Elymus cylindricus (GenBank accession No.:MK418452) and P. striiformis f. sp. agropyri on Agropyron cristatum (GenBank accession No.:MK418351). The related Puccinia species submitted at NCBI Database (https://www.ncbi.nlm.nih.gov/) were used as reference

Wang et al. 2018). Other forms of P. striiformis have not been reported with the exception of $P$. striiformis $\mathrm{f}$. sp. poae, which is now considered as a different species, $P$. pseudostriiformis (Abbasi et al. 2004; Liu and Hambleton 2010). In the present study, based on artificial inoculation and host specialization tests, we identified barberry (B. shensiana) as a potential alternate host for $\mathrm{f}$. sp. elymi, f. sp. agropyri, and f. sp. hordei of P. striiformis. Simultaneously, another barberry species, B. aggregata Schneid., native to China and collected from Tianshui of Gansu Province was used to test the susceptibility to the three formae speciales of $P$. striiformis. The results indicated that basidiospores of each of the three forms could also successfully infect $B$. aggregata and complete the pycnial and aecial stages. All the information suggested that, similar to P. striiformis f. sp. tritici and P. pseudostriiformis (syn. P. striiformis $\mathrm{f}$. sp. poae), the three forms of $P$. striiformis are heteroecious, macrocyclic rust fungi.

The determination of sexual stage of the three forms of $P$. striiformis facilitates studies on virulence variation through hybridization between different forms. Previous studies showed that hybridization of different formae speciales of $P$. graminis can result in new races of $P$. graminis $\mathrm{f}$. sp. tritici, the causal agent of wheat stem rust (Stakman et al. 1930). Johnson et al. (1932) made crosses of formae speciales, $P$. graminis tritici $\times P$. graminis secalis and $P$. graminis tritici $\times P$. graminis agrostidi on barberry plants, and obtained new variants from the progenies. B. shensiana has been reported as an alternate host for P. striiformis f. sp. tritici (Zhao et al. 2013). In this study, B. shensiana was identified as a potential alternate host for the three forms tested. It appears that barberry may serve as a common platform for different formae speciales to hybrid if simultaneous infections occur under natural conditions. Further studies are needed to test this hypothesis.

Uredinial hosts of $P$. striiformis are restricted in Gramineae family. The most susceptible genera include Aegilops, Agropyron, Bromus, Elymus, Hordeum, Secale, and Triticum (Stubbs 1985). Formae speciales differentiation of $P$. striiformis was primarily conducted based on host specialization (Eriksson 1894). The species of $P$. striiformis were divided into five formae speciales, namely Pst on wheat, Psh on barley, Pse on Elymus, Pss 

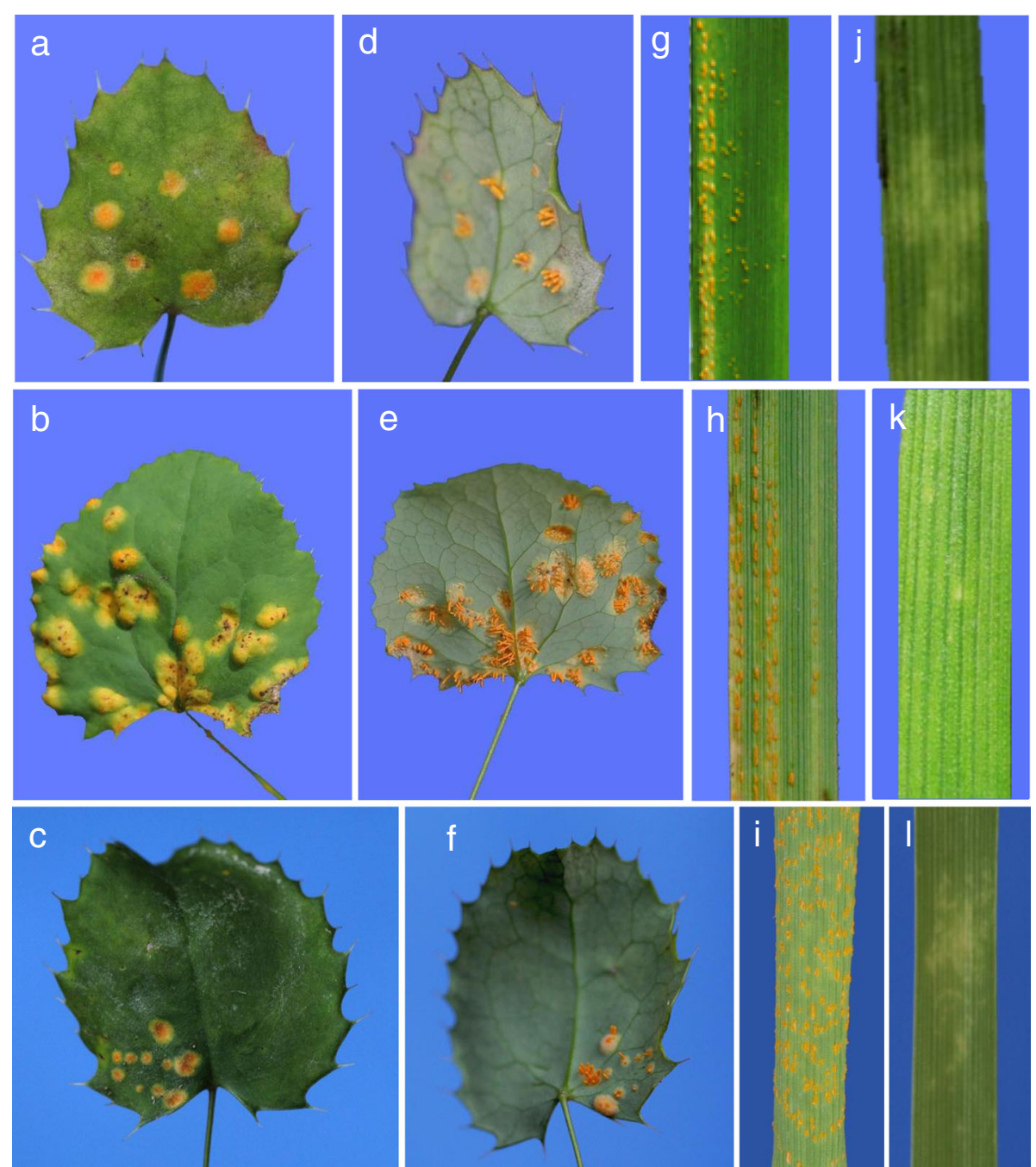

Fig. 4 Pycnial and aecial stages of each of formae speciales of Puccinia striiformis infecting Berberis. $\mathbf{a}, \mathbf{b}$, c Pycnial stage of Puccinia striiformis f. sp. agropyri, P. striiformis f. sp. elymi, and P. striiformis f. sp. hordei, on barberry (Berberis shensiana), respectively. d, e, $\mathbf{f}$ Aecial stage of $P$. striiformis f. sp. agropyri, $P$. striiformis f. sp. elymi, and P. striiformis f. sp. hordei, on barberry (B. shensiana), respectively. $\mathbf{g}, \mathbf{h}, \mathbf{i}$ Aeciospore infections of the three formae speciales of $P$. striiformis on respective original hosts, Elymus cylindricus, Agropyron cristatum, and barley cv. Guoluo (Hordeum vulgare var. nudum), after inoculation, respectively. j, k, I Reaction of wheat cv. Mingxian 169 seedlings inoculated with aeciospores of each of the three forms

on rye, and Psa on Agropyron. Subsequently, four more forms of $P$. striiformis, including $\mathrm{f}$. $\mathrm{sp}$. dactylidis, f. sp. poae, f. sp. leymi, and f. sp. pseudo-hordei, were reported by several researchers (Manners 1960; Tollenaa 1967; Niu et al. 1991; Wellings et al. 2000). Based on host specialization of $P$. striiformis, f. sp. hordei, f. sp. tritici, and f. sp. poae and DNA markers, Chen et al. (1995) determined that the three forms were different from each other, but the wheat and barley forms were more related to each other than to the bluegrass form. The forma specialis level of Pst and Psh was also confirmed at the genome level (Xia et al. 2018). According to spore morphology and molecular data, Liu and Hambleton (2010) classified P. striiformis into four lineages, including $P$. striiformis on Triticeae, $P$. striiformoides on
Dactylis glomerata, P. pseudostriiformis on Poa, and P. gansensis on Achnatherum inebrians. For the first lineage, $P$. striiformis, has the widest host range in tribe Triticeae, including Aegilops, Elymus, Hordeum, and Triticum.

Wild grasses are the primary hosts for P. striiformis in the original center (Hassebrauk 1965). Rust fungi in Uredinales are speculated to experience profound changes in either morphological or biological traits a couple of million years ago (Anikster and Wahl 1979). This indicates that cereal rust pathogens, including P. striiformis, have evolved with cultivation of crops during dissemination of the rust pathogen from the original area to other regions (Stubbs 1985). Under the pressure of host selection, $P$. striiformis has been acquiring new 
pathogenicity to produce different forms on crops and wild grass species. The present study may open the opportunity to study the genetic relationships between the different forms.

\section{Conclusions}

In the present study, we determined that barberries can serve as an alternate host for $P$. striiformis $\mathrm{f}$. sp. agropyri on Agropyron, f. sp. elymi on Elymus, and f. sp. hordei on Hordeum based on host specialization, spore morphology, and artificial inoculation. The results showed that these forms have their own specific primary hosts and their basidiospores can infect barberry and produce pycnia and aecia. The resulted aeciospores of these forms can further infect their respective primary hosts but not wheat. Thus we showed that barberry can serve as an alternate host for these formae speciales of $P$. striiformis.

\section{Methods}

Plants

Plants and seeds of two grass species, Agropyron cristatum (L.) Gaertn. and Elymus cylindricus (Franch.) Honda, were collected in Tianshui, Gansu Province during September to October 2013, and cultivated in greenhouse. The two grass species were identified by Zhenhai $\mathrm{Wu}$, a botanical researcher at College of Life Sciences, Northwest A\&F University, Yangling, Shaanxi, China (Additional file 3: Figure S3). Seeds of hulless barley cv. Guoluo (Hordeum vulgare L. var. nudum Hook) were kindly provided by Yuelin Peng at College of Plant and Pasture, Tibet University, Linzhi, Tibet, China. Young plants of barberry (Berberis shensiana Ahrendt) were transplanted from Baoji, Shaanxi Province and grown in the greenhouse to produce new leaves for later use. Seeds of A. cristatum, E. cylindricus, barley cv. Guoluo, susceptible to the barley stripe rust pathogen ( $P$. striiformis f. sp. hordei), and wheat $\mathrm{cv}$. Mingxian 169, susceptible to all known races of $P$. striiformis $\mathrm{f}$. sp. tritici (the causal pathogen of wheat stripe rust), were grown in pots filled with commercial mixed soil (Inner Mongolia Mengfei Biotech Co. Ltd., China). Two or three-leaf old wheat and barley cv. Guoluo seedlings and 5 or 6-leaf old grass seedlings were used for spore propagation and infection tests.

\section{Inoculum production and host specialization testing}

Stripe rust-infected leaf samples and plants of A. cristatum and E. cylindricus, were collected from Tianshui, Gansu in October, 2013 (Additional file 4: Figure S4). Leaf samples infected by the barley stripe rust fungus were collected in Linzhi, Tibet in June, 2013. To obtain pure stripe rust isolates of each of three forms of $P$. striiformis, a single uredinium produced on leaves of each of the two grass species and barley cv. Guoluo was picked to inoculate new leaves of the sample grass or barley $\mathrm{cv}$.
Guoluo. To test host specialization, urediniospores of the single uredinium-derived isolates were inoculated on three to five leaves of each of the two grass species and barley cv. Guoluo, and wheat cv. Mingxian 169 seedlings, respectively. Simultaneously, race CYR32 of $P$. striiformis f. sp. tritici was used to inoculate seedlings of wheat cv. Mingxian 169 as a control in all the tests. Inoculated plants of grasses and wheat were incubated in the dark at $10{ }^{\circ} \mathrm{C}$ for $24 \mathrm{~h}$ in dew chamber (I-36D, Percival, U.S.A.), and then transferred to a growth chamber at $13^{\circ} \mathrm{C}$ to $16^{\circ} \mathrm{C}$, and $16 \mathrm{~h}$ light and $8 \mathrm{~h}$ dark with light intensity of 8000 to $10,000 \mathrm{Lx}$. Reactions of the single uredinium isolates on grass and wheat plants were observed at 15 to $20 \mathrm{dpi}$ according to a scale of 0 to 4 (Li and Shang 1989).

\section{Teliospore preparation}

To prepare teliospores of the stripe rust isolates on two grass species and barley cv. Guoluo, the urediniospore-infected plants were kept in a growth chamber under the same conditions as mentioned above. Leaves bearing telia were collected and kept in a desiccator for a couple of weeks to 1 month at room temperature for later use.

\section{Morphological observation of urediniospores and teliospores}

Based on the determination of each form of $P$. striiformis by tests of host specialization, morphological characteristics of urediniospores and teliospores were observed using a light microscope (DP72, Olympus, Japan). Size of urediniospores and teliospores were determined by measuring approximately 100 spores using software cellSens attached by the microscope apparatus.

\section{PCR amplification and sequence analysis}

To further determine Agropyron form and Elymus form of $P$. striiformis, genome DNA of urediniospores were extracted using a Biospin Fungus Genomic DNA Extraction Kit (BioFlux, Tokoyo, Japan) according to the manual operation guide. The genomic DNA were amplified with primers Rust2inv (Aime 2006) and ITS4 (White et al. 1990) in a PCR thermal cycler (Applied Biosystems, MA, USA), with $P$. striiformis f. sp. tritici race CYR32 as a positive control. Each of the targeted bands was cloned into a pMD-T simple vector (TaKaRa, Japan) after PCR products were electrophoresed in an agarose gel. The clones were sequenced by Yangling Tianrun Aoke Biotech Co. Ltd. Sequence alignment was performed among the two grass species forms of $P$. striiformis and $P$. striformis f. sp. tritici race CYR32 using software DNAman (V 6.0, Lynnon). Sequences of the three forms of P. striiformis and that of the related Puccinia species retrieved from the NCBI database (https:// 
www.ncbi.nlm.nih.gov/) were used to construct phylogenic tree for taxa.

\section{Inoculation of rust fungi on barberry}

To test whether barberry can serve as the aecial hosts for the three forms of $P$. striiformis on the grass species and barley cv. Guoluo, leaf segments bearing teliospores were placed on $2 \%(\mathrm{w} / \mathrm{v})$ water agar medium in a Petri dish and kept at $16{ }^{\circ} \mathrm{C}$ in an incubator and periodically checked for teliospore germination. As teliospores began to germinate, a transparent cylinder made with an A4 paper-sized plastic film was used to enclose the young barberry plants and the dish was inverted to cover the top of the cylinder. The barberry plants were moved into an incubator for inoculation at $16^{\circ} \mathrm{C}$ and kept there for 3 days before being moved to a growth chamber. Infections of the barberry plants were observed periodically.

\section{Pathogenicity tests of aeciospores}

Aeciospores were used to inoculate seedlings of wheat and grass species. The inoculated plants were incubated in a dew chamber after inoculation and then in a growth chamber under the same conditions as described above. Reactions of wheat and the three grass species were recorded at 15 to $20 \mathrm{dpi}$. The same scales as mentioned above were used to determine the pathogenicity of aeciospores.

\section{Additional files}

Additional file 1: Figure S1. Alignment of ITS sequence of Puccinia striiformis f. sp. elymi, P. striiformis f. sp. agropyri, and P. striiformis f. sp. tritici. (PPTX $67 \mathrm{~kb}$ )

Additional file 2: Figure S2. Alignment of ITS sequence of Puccinia striiformis f. sp. elymi and P. striiformis f. sp. agropyri. (PPTX 59 kb)

Additional file 3: Figure S3. Plants and heads of grass species collected in Tianshui, Gansu Province in 2013 used in this study. a, b Agropyron cristatum (L.) Gaertn. c, d Elymus cylindricus (Franch.) Honda. (PPTX 1859 kb)

Additional file 4: Figure S4. Natural production of uredinia and telia of Puccinia striiformis infecting two grass species. a, b Agropyron cristatum. c, d Elymus cylindricus. (PPTX $1184 \mathrm{~kb}$ )

\section{Abbreviations}

cv.: Cultivar; f. sp.: Forma specialis (pl. formae speciales); Psa: Puccinia striiformis f. sp. agropyri; Pse: Puccinia striiformis f. sp. elymi; Psh: Puccinia striiformis f. sp. hordei; spp.: Species

\section{Acknowledgements}

We thank Guorong Wei for providing urediniospores of race CYR32 of Puccinia striiformis f. sp. tritici used in this study. We also thank Dr. Chongjing Xia from Department of Plant Pathology, Washington State University, Pullman, US and Dr. Chunlei Tang from College of Plant Protection, Northwest A\&F University, Yangling, Shaanxi, China, for English language polishing.

\section{Funding}

This study was financially supported by National Key R\&D Program of China (2018YFD0200500), the Natural Science Basic Research Plan in Shaanxi Province of China (2017JM3006), The Key Project of Science and Technology of Tibetan Autonomous Region, China (XZ201702NB15), the National Natural Science Foundation of China (31071641), and Program for New Century Excellent Talents in University (NCET-13-0490).

\section{Availability of data and materials}

Whole plants and seeds for these experiments were collected by Prof. Jie Zhao from Northwest A\&F University. Fungal materials were provided by Institution of Plant Pathology, Northwest A\&F University.

\section{Authors' contributions}

$J Z$ and ZK designed the experiments of the study. SH, SZ, DZ, YL, and ZD conducted experiments. SH, ZK and JZ wrote the paper. All the authors read and approved the final manuscript.

Ethics approval and consent to participate

Not applicable.

\section{Consent for publication}

Not applicable.

\section{Competing interests}

The authors declare that they have no competing interests.

Received: 28 October 2018 Accepted: 20 March 2019

Published online: 11 April 2019

\section{References}

Abbasi M, Hedjaroude G, Scholler M, Goodwin SB. Taxonomy of Puccinia striiformis s. I. in Iran. Rostaniha. 2004:5(2):71-82 199-224.

Aime MC. Toward resolving family-level relationships in rust fungi (Uredinales). Mycoscience. 2006;47(3):112-22.

Anikster Y, Wahl I. Coevolution of the rust fungi on Gramineae and Liliaceae and their hosts. Annu Rev Phytopathol. 1979;17:367-403.

Beresford RM. Stripe rust (Puccinia striiformis), a new disease of wheat in New Zealand. Cereal Rusts Bull. 1982;10(2):35-41.

Boshoff WHP, Pretorius Z, van Niekerk BD. Establishment, distribution, and pathogenicity of Puccinia striiformis f. sp. tritici in South Africa. Plant Dis. 2002; 86(5):485-92.

Brown JKM, Hovmøller MS. Epidemiology-aerial dispersal of pathogens on the global and continental scales and its impact on plant disease. Science. 2002; 297(5581):537-41.

Chen XM. Epidemiology and control of stripe rust [Puccinia striiformis f. sp. tritici] on wheat. Can J Plant Pathol. 2005;27(3):314-37.

Chen XM, Line RF, Leung $H$. Virulence and polymorphic DNA relationships of Puccinia striiformis f. sp. hordei to other rusts. Phytopathology. 1995;85(11): $1335-42$.

Cheng P, Chen XM, See RD. Grass hosts harbor more diverse isolates of Puccinia striiformis than cereal crops. Phytopathology. 2016;106(4):362-71.

Cummins GB. The rust fungi of cereals, grasses and bamboos. New York: Springer-Verlag New York Inc; 1971.

Eriksson J. Über die spezialisierung der parasitismus bei den getreiderostpilzen. Ber Deut Bot Ges. 1894;12:292-331.

Eriksson J, Henning E. Die Hauptresultate einer neuen Untersuchung über die Getreiderostpilze. Z Pflanzenkr. 1894;4:197-203.

Hassebrauk K. Nomenklatur, geographische, Verbreitung und Wirtsbereich des Gelbrostes, Puccinia striiformis West. Mitt Biol Bundesanst Land-Forstwirsch Berl-Dahl. 1965;116:1-75.

Hovmøller MS, Justesen AF, Brown JKM. Clonality and long-distance migration of Puccinia striiformis f. sp. tritici in north-West Europe. Plant Pathol. 2002;51(1): 24-32.

Jia QZ, Huang Q, Cao SQ, Zhang B, Wang XM, Jin SL. Discovery of new stripe rust strain infected to China's major wheat resistant material Guinong 22 and its preliminary pathogenicity analysis. Gansu Agr Sci Techn. 2012;1:3-5 (in Chinese).

Jin Y, Szabo L, Carson M. Century-old mystery of Puccinia striiformis life history solved with the identification of Berberis spp. as an alternate host. Phytopathology. 2010;100(5):432-5.

Johnson T, Newton M, Brown AM. Hybridization of Puccinia graminis tritici with Puccinia graminis secalis and Puccinia graminis agrostidis. Sci Agric. 1932;13(3): $141-53$.

Kuang WJ, Zhang GS, Zhang ZY, Ji HL, Shen L, Ni JY, et al. Studies on virulence of avrYr10/24/26/ch42 mutants of Puccinia strifformis f. sp. tritici. Southwest Chin J Agr Sci. 2013;26(6):2323-31 (in Chinese).

Li ZQ, Shang HS. Wheat rusts and its control. Shanghai: Shanghai Scientific \& Technical Publishers; 1989. 
Liu M, Hambleton S. Taxonomic study of stripe rust, Puccinia striiformis sensu lato, based on molecular and morphological evidence. Fungal Biol. 2010;114(10): 881-99.

Liu TG, Peng YL, Chen WQ, Zhang ZY. First detection of virulence in Puccinia striiformis f. sp. tritici in China to resistance genes Yr24 (=Yr26) present in wheat cv. Chuanmai 42. Plant Dis. 2010;94(9):1163.

Manners JG. Puccinia striiformis Westend. var. dactylidis var. nov. Trans Br Mycol Soc. 1960;43(1):65-8.

Murray GM, Ellison PJ, Watson A, Cullis BR. The relationship between wheat yield and stripe rust as affected by length of epidemic and temperature at the grain development stage of crop growth. Plant Pathol. 1994;43(2):397-405.

Niu YC, Li ZQ, Shang HS. Puccinia striiformis West. f. sp. leymi and f. Sp. elymi, two new formae speciales. J Northwest A\&F Univ (Nat Sci Ed). 1991;19:58-62 (in Chinese).

Rapilly F. Yellow rust epidemiology. Annu Rev Phytopathol. 1979:17:59-73.

Stakman EC, Levin MN, Cotter RU. Origin of physiologic forms of Puccinia graminis through hybridization and mutation. Sci Agric. 1930;10(11):707-20.

Stubbs RW. Stripe rust. In: Bushnell WR, Roelfs AP, editors. The cereal rusts, vol. II, diseases, distribution, epidemiology, and control. New York: Academic Press; 1985.

Tian Y, Zhan GM, Chen XM, Tungruentragoon A, Lu X, Zhao J, et al. Virulence and simple sequence repeat marker segregation in a Puccinia striiformis $\mathrm{f}$. sp. tritici population produced by selfing a Chinese isolate on Berberis shensiana. Phytopathology. 2016;106(2):185-91.

Tollenaa H. A comparison of Puccinia striiformis $\mathrm{f}$. Sp. poae on bluegrass with $P$. striiformis f. Sp. tritici and f. sp. dactylidis. Phytopathology. 1967;57(4):418-20.

Wan AM, Chen XM, He ZH. Wheat stripe rust in China. Aust J Agric Res. 2007; 58(6):605-19.

Wang L, Zhen D, Zuo SX, Chen XM, Zhuang H, Huang LL, et al. Inheritance and linkage of virulence genes in Chinese predominant race CYR32 of the wheat stripe rust pathogen Puccinia striiformis f. sp. tritici. Front Plant Sci. 2018;9:120

Wellings CR. Puccinia striiformis in Australia: a review of the incursion, evolution, and adaptation of stripe rust in the period 1979-2006. Aust J Agric Res. 2007; 58(6):567-75.

Wellings CR, Burdon JJ, Mclntosh RA, Wallwork H, Raman H, Murray GM. A new variant of Puccinia striiformis causing stripe rust on barley and wild Hordeum species in Australia. Plant Pathol. 2000;49(6):803.

White TJ, Bruns T, Lee S, Taylor J. Amplification and direct sequencing of fungal ribosomal RNA genes for phylogenies. In: Innis MA, Gelfand DH, Sninsky JJ, White TJ, editors. PCR protocols: a guide to methods and applications. San Diego: Academic Press; 1990.

Xia CJ, Wang M, Yin C, Cornejo OE, Hulber SH, Chen X. Genomic insights into host adaptation between the wheat stripe rust pathogen (Puccinia striiformis f. sp. tritici) and the barley stripe rust pathogen (Puccinia striiformis f. sp. hordei). BMC Genomics. 2018;19:664.

Zadoks JC. Yellow rust on wheat studies in epidemiology and physiologic specialization. Tijdschrift Over Plantenziekten. 1961;67(3):69-256 https://doi. org/10.1007/BF01984044.

Zadoks JC, van den Bosch F. On the spread of plant disease: a theory on foci. Annu Rev Phytopathol. 1994:32:503-21.

Zhao J, Wang L, Wang ZY, Chen XM, Zhang HC, Yao JN, et al. Identification of eighteen Berberis species as alternate hosts of Puccinia striiformis f. sp. tritic and virulence variation in the pathogen isolates from natural infection of barberry plants in China. Phytopathology. 2013;103(9):927-34.

Ready to submit your research? Choose BMC and benefit from:

- fast, convenient online submission

- thorough peer review by experienced researchers in your field

- rapid publication on acceptance

- support for research data, including large and complex data types

- gold Open Access which fosters wider collaboration and increased citations

- maximum visibility for your research: over $100 \mathrm{M}$ website views per year

At BMC, research is always in progress.

Learn more biomedcentral.com/submissions 